Jurnal Bisnis dan Manajemen, Volume 21, No. 2, September 2020, p. 100-113

\title{
MULTIGROUP ANALYSIS IN SUPPLY CHAIN PERFORMANCE
}

\author{
Erna Mulyati ${ }^{1}$ \\ Politeknik Pos, Indonesia
}

\begin{abstract}
This study aims to examine differences in private and government third-party logistics companies in Indonesia in terms of improving supply chain performance. In this research, supply chain performance testing is influenced by collaboration, radical innovation, and incremental innovation. The sample used is the third-party logistics industry in West Java and DKI Jakarta, totaling 100, which is divided into private third-party logistic companies and governmentowned third-party logistics companies. The results showed that there are differences in the effects of collaboration. There is supply chain performance where there are differences in the influence of collaboration and radical innovation on supply chain performance between private companies and government. There is no difference in the influence of collaboration and incremental innovation on supply chain performance between private companies and the government. The findings of this study indicate that radical and incremental innovation acts as a partial mediation on the effect of collaboration on supply chain performance in private and government companies.
\end{abstract}

Keywords: collaboration, radical innovation, incremental innovation, supply chain performance

\section{MULTIGRUP ANALYSIS KINERJA RANTAI PASOK}

\begin{abstract}
ABSTRAK
Penelitian ini bertujuan untuk menguji perbedaan pada perusahaan third party logistics di Indonesia milik swasta dan pemerintah dalam hal peningkatan kinerja rantai pasok. Pada penelitian ini pengujian kinerja rantai pasok dipengaruhi oleh kolaborasi, inovasi radikal dan inovasi inkremental. Sampel yang digunakan adalah industri third party logistic di Jawa Barat dan DKI Jakarta berjumlah 100 yang terbagi atas perusahaan third party logistic milik swasta dan third party logistic milik pemerintah. Hasil penelitian menunjukkan bahwa terdapat perbedaan pengaruh kolaborasi terdapat kinerja rantai pasok dimana terdapat perbedaan pengaruh kolaborasi dan inovasi radikal terhadap kinerja rantai pasok antara perusahaan swasta dan pemerintah. Tidak terdapat perbedaan pengaruh kolaborasi dan inovasi inkremental terhadap kinerja rantai pasok antara perusahaan swasta dan pemerintah. Temuan penelitian ini menunjukkan bahwa inovasi radikal dan inkremental berperan sebagai mediasi parsial pada pengaruh kolaborasi terhadap kinerja rantai pasok di perusahaan swasta maupun pemerintah.
\end{abstract}

Kata-kata Kunci: kolaborasi, inovasi radikal, inovasi inkremental, kinerja rantai pasok

${ }^{1}$ Korespondensi: Dr. Erna Mulyati, ST., MT. Politeknik Pos Indonesia. Jln. Sariasih No. 54, Bandung 40151, Indonesia. Email: ernamulyati@poltekpos.ac.id

Submitted: April 2020, Accepted: September 2020, Published: September 2020

ISSN: 1412 - 3681 (printed), ISSN: 2442 - 4617 (online), Website: http://journal.feb.unpad.ac.id/index.php/jbm 
Jurnal Bisnis dan Manajemen, Volume 21, No. 2, September 2022, p. 100-113

\section{INTRODUCTION}

In a competitive business environment, companies are beginning to realize the critical role of logistics and supply chain management in commercial transaction management that is used to create better value for customers (Alam, Bagchi, Kim, Mitra, \& Seabra, 2014). Supply chain management is the key to effective and efficient distribution (Abidi, de Leeuw, \& Klumpp, 2014). The supply chain is defined as a network of interdependent organizations and work together to control, regulate and increase the flow of material, money and supplier information to end-users (Alam et al., 2014; Balfaqih, Nopiah, Saibani, \& Al-Nory, 2016; Handfield \& Nichols, 2002; Mentzer et al., 2001). One service provider that plays an important role in the supply chain to customers is third party logistics (3PL). Third-party logistics is an external company that integrates and manages functions to facilitate the handling of company logistics activities (Cho, Ozment, \& Sink, 2008; Jothimani \& Sarmah, 2014; Kim, Yang, \& Kim, 2008; Tian, Ellinger, \& Chen, 2010). Third-party logistics can provide a sustainable competitive advantage in improving supply chain performance because it functions as a coordination mechanism. Besides, companies can reduce costs, increase core competencies and flexibility (Cheng \& Tang, 2014).

Supply chain performance is an essential tool for assessing the success rate of third party logistics (Jothimani \& Sarmah, 2014). This performance is a form of a manager's success in managing the supply chain efficiency by providing the necessary support (Balfaqih et al., 2016). According to the World Bank report in 2018 that the Indonesian logistics industry has increased its rank to 46 from 63 in 2016 globally and has declined in ASEAN from 4th to 5th position. Despite the improvement, Indonesia's logistics industry has lower logistics performance than Singapore, Thailand, Malaysia, and Vietnam. This performance impacts the Indonesian economy as a whole. The following Table 1 is the logistics performance index released by World Bank in 2018 for the ASEAN region.

Tabel 1. Logistic Performance Index

\begin{tabular}{lccc}
\hline Country & $\begin{array}{c}\text { LPI Rank } \\
\text { (Global) }\end{array}$ & $\begin{array}{c}\text { LPI Rank } \\
\text { (ASEAN) }\end{array}$ & $\begin{array}{c}\text { LPI } \\
\text { Score }\end{array}$ \\
\hline Singapore & 7 & 1 & 4.00 \\
Thailand & 32 & 2 & 3.41 \\
Vietnam & 39 & 3 & 3.27 \\
Malaysia & 41 & 4 & 3.22 \\
Indonesia & $\mathbf{4 6}$ & $\mathbf{5}$ & $\mathbf{3 . 1 5}$ \\
Philippines & 60 & 6 & 2.90 \\
Brunei & 80 & 7 & 2.71 \\
Laos & 82 & 8 & 2.70 \\
Cambodia & 98 & 9 & 2.58 \\
Myanmar & 137 & 10 & 2.30 \\
\hline
\end{tabular}

Source: World Bank, 2018

Table 1 shows that the logistics performance in Indonesia is still inferior compared to neighboring countries, namely Singapore, Thailand, Malaysia, where one of which plays a vital role in improving logistics performance is the role of logistics service providers. Presently, the government's attention is focused on business development and 
Jurnal Bisnis dan Manajemen, Volume 21, No. 2, September 2022, p. 100-113

increasing the competitiveness of logistics service providers; this is because the logistics services sector plays an important role and contributes to the logistics costs in the aggregate in Indonesia. At present, the ratio of logistics costs to Gross Domestic Product (GDP) is still relatively high, which ranges from $24 \%$ to $26 \%$ compared to other countries, namely the United States, the United Kingdom, and Germany, between $8 \%$ to $9 \%$. India $11 \%$ and China $17 \%$ (ADB, 2012), while from the component prices for retail products (consumer goods), logistics costs in Indonesia absorb $40 \%$ of the retail product sales prices. The most significant component of logistics costs, $72 \%$, is transportation costs (Zaroni, 2017). So, it is crucial for companies in the logistics industry to better measure supply chain performance to reduce transportation costs.

Measuring supply chain performance in the logistics industry requires companies to include the right parameters to ensure a balanced framework. Jothimani and Sarmah (2014) stated that in measuring the supply chain performance of a company, it not only considers the effectiveness and efficiency aspects but looks at the internal aspects as well as the relationships with its customers. Measurement of supply chain performance is a quantitative process of effectiveness and efficiency of operations that requires several indicators to measure objectives rather than the company's supply chain (Abidi et al., 2014). This is because logistical performance is a subset of a broader concept than company performance. Abidi et al. (2014) state that a lot of added value is obtained by measuring supply chain performance, which cannot be disclosed commercially, but many companies have benefited significantly from supply chain performance.

Several previous studies have shown that to achieve a competitive advantage between parties in improving supply chain performance, that is by strengthening their collaboration activities (Cheng \& Tang, 2014). The same is stated that collaboration is a critical success factor in supply chain performance in a business environment (Kang, Moon, \& Moon, 2015). The advantages of collaboration in the supply chain include saving costs, increasing capacity and flexibility, better decision making, increasing revenue through resource synergies, and innovation in exchanging ideas (Hansen \& Nohria, 2004). In addition to collaboration, innovation serves as an addition or reduction of risk in business (Klein-Schmeink \& Peisl, 2013; Kwak, Seo, \& Mason, 2018). Innovation in supply chains provides new ways for better processes (Lee, Lee, \& Schniederjans, 2011). For many types of innovation, this study uses the variables of radical innovation and incremental innovation (Chapman, Soosay, \& Kandampully, 2002). Radical innovation is more at a high level of novelty, to make significant changes for the better by involving many challenges and opportunities (Sen \& Ghandforoush, 2011). Meanwhile, incremental innovation is an innovation with a low novelty 
Jurnal Bisnis dan Manajemen, Volume 21, No. 2, September 2022, p. 100-113

level and lower risks and costs than radical innovation.

The logistics industry in Indonesia is divided into two, namely the private-owned logistics industry and the government-owned logistics industry (BUMN). Both have advantages and disadvantages for each. For example, government property is superior in networks, but private is strong in speed and information technology. Based on the previous explanation, in this paper, we want to see the supply chain performance in private and government third-party logistic companies. Supply chain performance will be seen based on collaboration, radical innovation, and increment innovation.

\section{LITERATURE REVIEW}

The use of resources, flexibility, and desired outputs have been used successfully as important components to measure supply chain performance. Therefore, a supply chain measurement system must emphasize three separate types of performance measurement, namely: measurement of resources (R), output measurement $(\mathrm{O})$, and flexibility measurement (F). Each type of measurement has important characteristics and each measurement affects the others. Therefore, supply chain performance measurement systems must contain at least one of the three characteristics above. This measurement system allows interaction between the three or can guarantee the achievement of the desired level of performance in each area (Beamon, 1999).

Donald, David, and Bixby (2002) propose key performance indicators (KPI) to assess supply chain performance collaborating in supply chains, based on functional perspective categories, as follows: 1) Management Costs: i.e., costs incurred as a result of meeting operational activities, which includes: total costs, transportation costs, damage to goods, storage costs, and the cost of order delays. 2) Customer Service: i.e., logistical operational aspects that ensure the company can provide seven rights to customers in the form of the right amount, right product, right time, right place, right quality, the right price, and right information. 3) Quality: namely the accuracy of the company's logistics operational activities, including the accuracy of the order, the accuracy of the packing/shipping, the accuracy of the information, the accuracy of the documents, and the availability of information. 4) Productivity: i.e., the ratio or index between outputs (goods, work completion, services produced $)$ and input $=($ resources used to produce products or services), which include: warehouse labor productivity, transportation labor productivity, equipment downtime, and productivity index. 5) Asset Management: i.e., utilization of capital investment for facilities and equipment, which is stated as a working capital investment in inventory, which includes: inventory turnover (number of goods sold in a period / average inventory in a period), return on 
Jurnal Bisnis dan Manajemen, Volume 21, No. 2, September 2022, p. 100-113

assets (net profit margin $\mathrm{x}$ asset turn over), and inventory that has expired.

Chan and Qi (2003) propose the measurement of key performance indicators (KPI), which they call the Performance of Activity (POA). In principle, the POA is a model used to measure the performance of activities that are part of the process in the supply chain. Activity performance is measured in various dimensions, namely:

1) Costs, which are involved in the execution of an activity. In this case, costs can be associated with transportation, warehousing, labor, and administration costs.

2) Time, which is needed to do an activity. This measure is essential in the context of supply chain management, especially for supply chains that compete based on response speed.

3) Capacity is a measure of how much volume of work a system or part of a supply chain can do in a given period. The amount of installed capacity relative to the average demand provides flexibility in supply chain information.

4) Capability refers to the aggregate ability of a supply chain to carry out an activity. Several sub-dimensions make up the supply chain capability.

5) Utilization measures the level of resource use in supply chain activities. For example, utility vehicles and warehouses.

The Supply Chain Operation Reference (SCOR) model developed by The Supply Chain Council is a strategic planning tool that enables senior managers to simplify the complexity of supply chain management (Huan, Sheoran, \& Wang, 2004). Performance measurements based on the SCOR model include (1) reliability, (2) responsiveness, (3) flexibility, (4) costs, and (5) assets management.

1. Reliability - improving company performance in providing logistics services to customers to manage company logistics successfully: right product, right quantity, right time, right place, right condition and packing, and right cost. Reliability performance measures such as Delivery Performance, Fill Rates, and Product Order Fulfillment measure the success of logistics and supply chain management.

2. Responsiveness-The speed and responsiveness of the company in managing the order cycle time and the response time of customers in providing their products to the market or customers. Lead Times' Fulfillment Order is one measure of responsiveness performance.

3. Flexibility-The company runs its business processes with high standard procedures, and the level of compliance with strict SOPs, supply chain flexibility in responding to market changes to increase competitive advantage. Performance measures of flexibility commonly used are Supply Chain Response Time and Production Flexibility.

4. Costs-The total costs associated with managing logistics and supply chain. Measuring the performance of supply chain costs as a measure of the success of managing logistics and supply chain customers, among 
Jurnal Bisnis dan Manajemen, Volume 21, No. 2, September 2022, p. 100-113

others: Cost of Goods Sold, Total Supply

Chain Management Costs, Value-Added Productivity, and Warranty / Returns Processing Costs.

5. Asset management-managing customer logistics to increase the effectiveness of customer assets. Measures of supply chain asset management efficiency performance include Cash-to-Cash Cycle Time, Inventory Days of Supply, and Asset Turn.

Performance measurement in this study is based on the SCOR model to measure supply chain performance in Third Party Logistics companies with partners. At present, collaboration variables are an important issue, especially if emphasized on improving supply chain performance. Previous research has also explained that factors that are important components to improve supply chain performance, namely collaboration and innovation (Ha, Park, \& Cho, 2011; Narayanan, Narasimhan, \& Schoenherr, 2015; Tsanos \& Zografos, 2016; Wu, Chuang, \& Hsu, 2014).

The conceptual model in this research is related to collaboration, radical innovation, and incremental innovation on supply chain performance, both direct and indirect effects on third-party logistics as seen from company ownership, namely private and government.

\section{Collaboration and Supply Chain Performance}

Research results on the effect of collaboration on supply chain performance have been conducted by Tsanos and Zografos (2016); Narayanan et al.
(2015); Wu et al. (2014); Ha et al. (2011), where the results of empirical analysis show a significant positive effect between collaboration on supply chain performance. Statements from several researchers above provide understanding for researchers to propose a hypothesis as follows:

H1: Differences in the effect of collaboration on the supply chain performance of private and government third-party logistic companies.

\section{Collaboration and Innovation}

Swink (2006) asserted that organizations that can collaborate are the key to successful innovation. It shows that collaboration becomes something essential and can be implemented in companies in increasing innovation. Innovation implies that a company must proactively explore new opportunities and not merely exploit current strengths. The intended innovation is radical innovation where the innovation leads to the launch of new products or services and incremental innovations that focus on problems and processes of organizational improvement, namely improving management practices, streamlining organizational structures, adjusting services, improving networks, and improving distribution (Dewar \& Dutton, 1986; Howells, 2000). Innovation is expected to produce major changes and can affect supply chain performance.

The results of Soosay, Hyland, and Ferrer (2008) research show that different collaboration relationships and different company capacities 
Jurnal Bisnis dan Manajemen, Volume 21, No. 2, September 2022, p. 100-113

will have an impact on different operations in innovation. The ability to work with partners enables companies to integrate operational activities in increasing effectiveness and innovating, both radically and incrementally. Simatupang and Sridharan (2005) explain that supply chain members in collaborative practice will be able to achieve better operational and innovation activities. Statements from several researchers above provide understanding for researchers to propose a hypothesis as follows:

H2: Differences in the effect of collaboration on the radical innovations of private and third-party government logistics companies

H3: Differences in the effect of collaboration on the incremental innovations of private and thirdparty government logistics companies

\section{Innovation and Supply Chain Performance}

In the context of supply chain management that innovation is crucial to supply chain integration (Rutner, Gibson, \& Williams, 2003), for example, building relationships between companies and customers in sending and receiving information and giving satisfaction to customers (Stefansson, 2002). Therefore, openness to new ideas and the adoption of new technologies will lead to improved supply chain performance. Lin, Wang, and Yu (2010) explain that Value Cocreation and Value Constellations as the main drivers of innovation in channel integration have a significant positive relationship with supply chain performance. Panayides and Lun (2009) show that trust and innovation as antecedents that affect supply chain performance. The intended innovation is a new process, a new method, a new way that can improve logistics performance, but the assessment is carried out by one party. The indicators used are very general and still biased so the model still cannot be generalized. Statements from several researchers above provide understanding for researchers to propose a hypothesis as follows:

H4: Differences in the influence of radical innovation on supply chain performance in private and third-party government logistics companies

H5: Differences in incremental innovation on supply chain performance in private and thirdparty government logistics companies

Figure 1. shows the research model of this study.

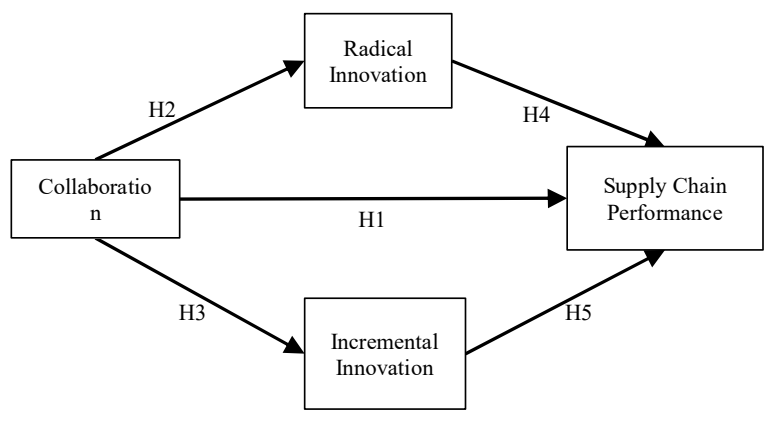

Figure 1. Research Model

\section{METHODS}

This study uses a positivist research approach, namely quantitative research to measure the constructs that shape the model and analyze the effects of one construct with other constructs 
Jurnal Bisnis dan Manajemen, Volume 21, No. 2, September 2022, p. 100-113

(Creswell, 2014). Hair, Black, Babin, and Rolph (2010) explained that the size of group sample members must be greater than the number of independent variables. In the hypothesis, the model consists of 3 independent variables, namely collaboration, radical innovation, and incremental innovation with a total of 14 items.

In this study, the sample used in the logistics industry is third-party logistics companies totaling 100 , with details of private third-party logistics totaling 83 companies and government-owned totaling 17 companies. The proportion of private and government third-party logistic sampling is based on the smallest number of samples in one group, at least greater than the number of independent variables. Because this model is latent, the reason for determining the number of samples is the number of manifest variables, namely the total number of items. This study aims to look at supply chain performance in the private and government third-pasty logistics industry, which is influenced by collaboration, radical innovation, and incremental innovation. Analysis of this study using PLS-SEM with SmartPLS software (v.3.2.7) (Ringle, Sarstedt, Mitchell, \& Gudergan, 2018).

Data was collected through a questionnaire from November 2019 to March 2020. The respondents who filled out were people who truly understood the company's operational activities (strategic level), namely the director or senior operational manager or operational manager. If related to the modeling plan using structural equation modeling (SEM) and latent variables of five or less (Hair Jr et al., 2010), the minimum required sample is 100 . Based on these considerations, the number of sample companies in this study is a minimal 100 companies, so 1 respondent or more will be taken from each company. The total respondents obtained were 100 respondents from 100 companies.

\section{RESULTS AND DISCUSSION Outer Model Results}

The outer model is an assessment of the validity and reliability of research variables (Hair Jr, Ringle, Sarstedt, \& Gudergan, 2017). There are three criteria for assessing the outer model, namely the validity of the validity (loading factor $>0.5$ ), composite reliability (composite reliability and Cronbach's alpha $>0.7$ ), and convergent validity (AVE $>0.5)$. These values can be shown in Table 2 below.

Tabel 2. Outer Model Result

\begin{tabular}{|c|c|c|c|c|c|c|c|c|}
\hline \multirow{2}{*}{ Indicator } & \multicolumn{2}{|c|}{ Loading Factor } & \multicolumn{2}{|c|}{$\begin{array}{l}\text { Composite } \\
\text { Reliability }\end{array}$} & \multicolumn{2}{|c|}{$\begin{array}{l}\text { Cronbach's } \\
\text { alpha }\end{array}$} & \multicolumn{2}{|c|}{ AVE } \\
\hline & $\mathrm{P}$ & $\mathrm{G}$ & $\mathrm{P}$ & $\mathrm{G}$ & $\mathrm{P}$ & $\mathrm{G}$ & $\mathrm{P}$ & $\mathrm{G}$ \\
\hline \multicolumn{9}{|l|}{ Collaboration } \\
\hline Commitment & $0.458^{*}$ & $0.432 *$ & \multirow{8}{*}{0.876} & \multirow{8}{*}{0.900} & \multirow{8}{*}{0.832} & \multirow{8}{*}{0.867} & \multirow{8}{*}{0.507} & \multirow{8}{*}{0.568} \\
\hline Coordination & 0.797 & 0.809 & & & & & & \\
\hline Trust & 0.798 & 0.856 & & & & & & \\
\hline Communication & 0.745 & 0.586 & & & & & & \\
\hline Conflict & 0.723 & 0.704 & & & & & & \\
\hline $\begin{array}{l}\text { Joint Decision } \\
\text { Making }\end{array}$ & 0.774 & 0.927 & & & & & & \\
\hline $\begin{array}{l}\text { Sharing } \\
\text { information }\end{array}$ & 0.525 & 0.658 & & & & & & \\
\hline $\begin{array}{l}\text { Benefit/Risk } \\
\text { Sharing }\end{array}$ & 0.548 & 0.677 & & & & & & \\
\hline \multicolumn{9}{|c|}{ Radical Innovation } \\
\hline $\begin{array}{l}\text { Management } \\
\text { Method }\end{array}$ & 0.864 & 0.801 & \multirow{3}{*}{0.910} & \multirow{3}{*}{0.900} & \multirow{3}{*}{0.852} & \multirow{3}{*}{0.832} & \multirow{3}{*}{0.772} & \multirow{3}{*}{0.751} \\
\hline Process & 0.934 & 0.937 & & & & & & \\
\hline Technology & 0.835 & 0.857 & & & & & & \\
\hline \multicolumn{9}{|c|}{ Incremental Radical } \\
\hline $\begin{array}{l}\text { Management } \\
\text { Method }\end{array}$ & 0.903 & 0.922 & \multirow{3}{*}{0.846} & \multirow{3}{*}{0.853} & \multirow{3}{*}{0.727} & \multirow{3}{*}{0.749} & \multirow{3}{*}{0.650} & \multirow{3}{*}{0.662} \\
\hline Process & 0.705 & 0.805 & & & & & & \\
\hline Technology & 0.798 & 0.698 & & & & & & \\
\hline \multicolumn{9}{|c|}{ Supply Chair Performance } \\
\hline Reliability & $0.410^{*}$ & 0.894 & \multirow{5}{*}{0.857} & \multirow{5}{*}{0.925} & \multirow{5}{*}{0.780} & \multirow{5}{*}{0.897} & \multirow{5}{*}{0.603} & \\
\hline Responsiveness & 0.606 & 0.863 & & & & & & \\
\hline Flexibility & 0.759 & 0.717 & & & & & & 0.712 \\
\hline Costs & 0.859 & 0.876 & & & & & & \\
\hline $\begin{array}{l}\text { Asset } \\
\text { Management }\end{array}$ & 0.819 & 0.856 & & & & & & \\
\hline
\end{tabular}


Jurnal Bisnis dan Manajemen, Volume 21, No. 2, September 2022, p. 100-113

$\mathrm{P}=$ Private $\mathrm{G}=$ Government

$*=$ an indicator with a loading factor $<0.5$, so that it will be evaluated by conducting further analysis without the indicator (commitment to collaboration and reliability on supply chain performance)

\section{Model Suitability}

Model suitability can be measured by two model suitability indices, namely the model determinant coefficient (R2) and the goodness of fit (GoF) coefficient (Hair Jr et al., 2017). The determinant coefficient of the model is calculated by using all the coefficient of determination $\left(\mathrm{R}^{2}\right)$ in the model. $\mathrm{R}^{2}$ calculation results can be seen in the following Table 3.

Tabel 3. R-Square Result $\left(\mathbf{R}^{2}\right)$

\begin{tabular}{lcc}
\hline \multirow{2}{*}{ Dependent Variable } & \multicolumn{2}{c}{$\mathrm{R}^{2}$} \\
\cline { 2 - 3 } & $\begin{array}{c}\text { Private } \\
\text { companies }\end{array}$ & $\begin{array}{c}\text { Government } \\
\text { companies }\end{array}$ \\
\hline Radical innovation & 0,266 & 0,779 \\
Incremental innovation & 0,288 & 0,598 \\
Supply chain performance & 0,707 & 0,868 \\
\hline
\end{tabular}

At the GoF value to measure how well the model is produced. The amount of GoF has a range of values $0-1$. A value closer to 1 means the model is better (Hair Jr et al., 2017).

Tabel 4. Goodness of Fit (GoF) Index

\begin{tabular}{lcccc}
\hline \multirow{2}{*}{ Variable } & \multicolumn{2}{c}{ Private companies } & \multicolumn{2}{c}{ Government companies } \\
\cline { 2 - 5 } & Communality & $\mathrm{R}^{2}$ & Communality & $\mathrm{R}^{2}$ \\
\hline Collaboration & 0.507 & & 0.568 & \\
$\begin{array}{l}\text { Radical } \\
\text { innovation }\end{array}$ & 0.772 & 0.266 & 0.751 & 0.779 \\
$\begin{array}{l}\text { Incremental } \\
\text { innovation }\end{array}$ & 0.650 & 0.288 & 0.662 & 0.598 \\
Supply chain & 0.603 & 0.707 & & 0.712 \\
performance & 2.532 & 1.261 & 2.693 & 2.245 \\
Total & 0.633 & 0.420 & 0.673 & 0.748 \\
Mean & 0.516 & & 0.710 & \\
GoF Index & & & &
\end{tabular}

The GoF index for this research model is 0.519 in private companies and 0.710 in government. Thus, the structural model that explains the relationship between the four variables has good predictive power (fit).

\section{Inner Model Results}

The inner model aims to determine the path coefficient and t-statistics that indicate the level of significance of changes in the independent variable on the dependent variable (Hair Jr et al., 2017). Hypothesis models are calculated to determine the significance of the path coefficients in the model or the significance of the hypothesis support. Path coefficient, significant if $p<0.05$, the results of the inner model are explained in Table 5 below.

Tabel 5. Path Coefficient in the Inner Model

\begin{tabular}{|c|c|c|c|}
\hline Variable relationship & $\begin{array}{c}\text { Path } \\
\text { coefficient }\end{array}$ & $\begin{array}{c}\mathrm{T} \\
\text { Statistics } \\
\end{array}$ & $\mathrm{P}$ \\
\hline \multicolumn{4}{|l|}{ Private companies } \\
\hline Collaboration $->$ Radical Innovation & 0.516 & 8.263 & 0.000 \\
\hline Collaboration -> Incremental Innovation & 0.537 & 8.574 & 0.000 \\
\hline $\begin{array}{l}\text { Collaboration -> Supply Chain } \\
\text { Performance }\end{array}$ & 0.166 & 2.413 & 0.016 \\
\hline $\begin{array}{l}\text { Radical Innovation -> Supply Chain } \\
\text { Performance }\end{array}$ & 0.559 & 6.864 & 0.000 \\
\hline $\begin{array}{l}\text { Incremental Innovation -> Supply Chain } \\
\text { Performance }\end{array}$ & 0.263 & 3.109 & 0.002 \\
\hline \multicolumn{4}{|l|}{ Government companies } \\
\hline Collaboration $->$ Radical Innovation & 0.883 & 13.900 & 0.000 \\
\hline $\begin{array}{l}\text { Collaboration -> Incremental } \\
\text { Innovation }\end{array}$ & 0.778 & 13.595 & 0.000 \\
\hline $\begin{array}{l}\text { Collaboration -> Supply Chain } \\
\text { Performance }\end{array}$ & 0.693 & 2.685 & 0.007 \\
\hline $\begin{array}{l}\text { Radical Innovation -> Supply Chain } \\
\text { Performance }\end{array}$ & 0.112 & 0.410 & $0.682 * *$ \\
\hline $\begin{array}{l}\text { Incremental Innovation -> Supply } \\
\text { Chain Performance }\end{array}$ & 0.173 & 0.795 & $0.427 * *$ \\
\hline \multicolumn{4}{|l|}{ Difference coefficient } \\
\hline Collaboration -> Radical Innovation & 0.367 & 2.616 & 0.010 \\
\hline $\begin{array}{l}\text { Collaboration -> Incremental } \\
\text { Innovation }\end{array}$ & 0.241 & 1.721 & 0.088 \\
\hline $\begin{array}{l}\text { Collaboration -> Supply Chain } \\
\text { Performance }\end{array}$ & 0.527 & 2.804 & 0.006 \\
\hline $\begin{array}{l}\text { Radical Innovation -> Supply Chain } \\
\text { Performance }\end{array}$ & 0.447 & 2.086 & 0.040 \\
\hline $\begin{array}{l}\text { Incremental Innovation -> Supply } \\
\text { Chain Performance }\end{array}$ & 0.090 & 0.432 & 0.667 \\
\hline
\end{tabular}

The results of research on the private sector showed that the direct path coefficient was tested significantly. Nevertheless, the research results 
Jurnal Bisnis dan Manajemen, Volume 21, No. 2, September 2022, p. 100-113

of government companies are not all significant in the path coefficients tested. Proof of differences in modeling results in the two groups was analyzed using multigroup analysis (MGA) by testing the difference in the coefficient of direct and indirect effects. The effect of collaboration on supply chain performance is stronger in government companies (by a difference of $0.527 ; 0.367 ; 0.241)$. The influence of radical innovation and incremental innovation on supply chain performance is stronger in private companies (with a difference of 0.447 ; 0.090).

In Table 6, collaboration on supply chain performance has an indirect effect through radical innovation and incremental innovation.

Tabel 6. Result of Indirect Effect

\begin{tabular}{|c|c|c|c|c|c|c|}
\hline & $\begin{array}{c}\text { Coefficient } \\
\text { of indirect } \\
\text { effect }\end{array}$ & $\begin{array}{c}\mathrm{T} \\
\text { Statistics }\end{array}$ & $\mathrm{P}$ & $\begin{array}{l}\text { Total } \\
\text { Effect }\end{array}$ & VAF & Decision \\
\hline \multicolumn{7}{|c|}{ Private companies } \\
\hline $\begin{array}{l}\text { Collaboration -> } \\
\text { Supply Chain } \\
\text { Performance }\end{array}$ & 0.429 & 7.699 & 0.000 & 0.595 & $72.1 \%$ & $\begin{array}{c}\text { Partial } \\
\text { Mediation }\end{array}$ \\
\hline \multicolumn{7}{|c|}{ Government companies } \\
\hline $\begin{array}{l}\text { Collaboration -> } \\
\text { Supply Chain } \\
\text { Performance }\end{array}$ & 0.233 & 0,986 & 0.325 & 0.926 & $25.2 \%$ & $\begin{array}{c}\text { Partial } \\
\text { Mediation }\end{array}$ \\
\hline \multicolumn{7}{|c|}{ Difference coefficient } \\
\hline $\begin{array}{l}\text { Collaboration -> } \\
\text { Supply Chain } \\
\text { Performance }\end{array}$ & 0.196 & 1.228 & 0.222 & & & \\
\hline
\end{tabular}

The indirect effect on supply chain performance is the magnitude of influence obtained from the product of all paths traversed. The indirect effect of collaboration on supply chain performance through radical innovation and incremental innovation is $0.143(\mathrm{p}=0.003)$ in private companies and $0.233(\mathrm{p}=0.325)$ in government companies. The difference in the indirect effect of 0.196 was higher in private companies but tested insignificant. This result can be interpreted that the effect of increasing the high supply chain is a positive effect of the high radical innovation and incremental innovation caused by the application of good collaboration with other companies. This research contributes to Third-Party Logistics companies with their partners in operational management, especially proving in the views of managers in logistics service companies that the importance of collaboration, radical innovation, incremental innovation in improving supply chain performance. The effect of collaboration is stronger on supply chain performance in government-owned companies where the company together with partners is supported by commitment and performance that always exceeds customer desires, sharing information related to sharing sales data, customer data, shipping data and willing to share benefits and risks, which has rules under the principle of reward and risk-sharing and has a policy of market development, customer acquisition and improvement of service quality to create mutual benefits. However, unlike private companies where the influence of radical innovation and incremental innovation is stronger on supply chain performance. The creation of revolutionary innovations with integrated technology plays an important role in radical innovation. Companies can create new ideas, new processes, new methods, or new services in the context of the supply chain supported by revolutionary technology both in the field of automation and 
Jurnal Bisnis dan Manajemen, Volume 21, No. 2, September 2022, p. 100-113

ICT technology. For academics, this research contributed to the development of management science, especially logistics management and supply chains as part of operational management.

Based on the test results, there are direct and indirect influences. On the differences in collaboration on supply chain performance between private and government companies, the results of the study prove the difference in the two types of companies. So, it can be concluded that there are differences between private and government companies in the company's ability to collaborate, which directly improves supply chain performance. Empirically the results of this study also show that collaboration can improve supply chain performance and support research results of Tsanos and Zografos (2016); Narayanan et al. (2015); Wu et al. (2014); Ha et al. (2011).

On the difference of collaboration on radical innovation between private and government companies, the results of the study prove the difference in the two types of companies. So, it can be concluded that there are differences between private and government companies in the company's ability to collaborate, which directly increases radical innovation. Empirically the results of this study also show that collaboration can increase radical innovation in logistics companies and support the results of research of Soosay et al. (2008); Simatupang and Sridharan (2005).

On the differences in collaboration on incremental innovation between private and government companies, the results of the study do not prove the difference between the two types of companies. So, it can be concluded that there is no difference between private companies and the government on the company's ability to collaborate, which directly increases incremental innovation. However, these results indicate that collaboration increases incremental innovation in logistics companies and supports Simatupang and Sridharan (2005); Soosay et al. (2008).

Differences in radical innovation on the supply chain performance between private companies and government, the results of the study prove the difference in the two types of companies. So it can be concluded that there are differences between private and government companies in the company's ability to perform radical innovations that directly improve supply chain performance and support the research results of Lin et al. (2010); Panayides and Lun (2009).

Differences in incremental innovation on supply chain performance between private and government companies, the results of the study do not prove the difference in the two types of companies. So, it can be concluded that there is no difference between private companies and the government on the company's ability to carry out incremental innovations that directly improve supply chain performance. However, these results indicate that incremental innovation can improve supply chain performance in logistics companies owned by the private sector and 
Jurnal Bisnis dan Manajemen, Volume 21, No. 2, September 2022, p. 100-113

support the results of the research of Panayides and Lun (2009); Lin et al. (2010).

Research findings on the indirect effect of both private and government companies, radical innovation, and incremental innovation act as partial mediations on the effect of collaboration on supply chain performance. Acting as a partial or partial mediation means that the variables of radical innovation and incremental innovation contribute part of their role to the relationship between collaboration variables and supply chain performance. Thus, these findings indicate that innovation is still needed by logistics companies when collaborating between companies to improve supply chain performance in companies to be better, even though basically collaboration itself can improve supply chain performance. In private companies, the role of innovation is far greater than that of government companies. This is because private companies are demanded to be more innovative in establishing good relations between logistics companies.

\section{CONCLUSION}

The findings in this study indicate that there are differences in third-party logistic companies owned by the private and government sectors. First, in the differences in collaboration on supply chain performance, government companies are far stronger than private companies. Second, the differences in the effect of collaboration on radical innovation, government companies are much stronger than private companies. Third, in the difference in the influence of radical innovation on supply chain performance is much stronger for private companies. These results indicate that in private third-party logistics companies still need to work hard in strengthening collaboration to improve supply chain performance and radical innovation, as well as government-owned third-party logistics companies to do more radical innovations or incremental innovations to improve supply chain performance. Increasing radical and incremental collaboration and innovation in private and government companies is a way to improve Indonesia's logistics performance index in the global industry and especially ASEAN.

This study has some limitations. This research does not consider aspects of the period time of collaboration so that it affects the commitment of resources that must be shared to achieve the maturity of collaboration. Besides, some companies only collaborate (by project), so they cannot build a good collaboration between companies and partners. This study also did not identify the initial segmentation of the type of distribution for international or domestic coverage, the strategy of companies that have based assets or non-based assets. Thus, it will significantly affect the differences in capabilities and competitiveness of third-party logistics companies.

\section{REFERENCES}

Abidi, H., de Leeuw, S., \& Klumpp, M. (2014). Humanitarian Supply Chain Performance Management: a Systematic Literature Review. 
Jurnal Bisnis dan Manajemen, Volume 21, No. 2, September 2022, p. 100-113

Supply Chain Management: An International Journal.

Alam, A., Bagchi, P. K., Kim, B., Mitra, S., \& Seabra, F. (2014). The mediating effect of logistics integration on supply chain performance. The International Journal of Logistics Management.

Balfaqih, H., Nopiah, Z. M., Saibani, N., \& Al-Nory, M. T. (2016). Review of supply chain performance measurement systems: 1998-2015. Computers in Industry, 82, 135-150.

Beamon, B. M. (1999). Measuring Supply Chain Performance. International Journal of Operations \& Production Management.

Chan, F. T., \& Qi, H. (2003). Feasibility of performance measurement system for supply chain: a process-based approach and measures. Integrated manufacturing systems.

Chapman, R. L., Soosay, C., \& Kandampully, J. (2002). Innovation in logistic services and the new business model: a conceptual framework. Managing Service Quality: An International Journal.

Cheng, J.-H., \& Tang, C.-H. (2014). Interorganizational cooperation and supply chain performance in the context of third party logistics services.

Cho, J. J.-K., Ozment, J., \& Sink, H. (2008). Logistics capability, logistics outsourcing and firm performance in an e-commerce market. International journal of physical distribution \& logistics management, 38(5), 336-359.

Creswell, J. W. (2014). A concise introduction to mixed methods research: SAGE publications.

Dewar, R. D., \& Dutton, J. E. (1986). The adoption of radical and incremental innovations: An empirical analysis. Management science, 32(11), 1422-1433.

Donald, J. B., David, C., \& Bixby, C. (2002). Supply chain logistics management. Michigan State: McGraw Hill.

Ha, B. C., Park, Y. K., \& Cho, S. (2011). Suppliers' affective trust and trust in competency in buyers. International Journal of Operations \& Production Management.

Hair Jr, J. F., Black, W. C., Babin, B. J., \& Anderson Rolph, E. (2010). Multivariate data analysis: Pearson Education.

Hair Jr, J. F., Ringle, C., Sarstedt, M., \& Gudergan, S. P. (2017). Advanced issues in partial least square structural equation modeling. SAGE.

Handfield, R. B., \& Nichols, E. L. (2002). Supply chain redesign: Transforming supply chains into integrated value systems: Ft Press.
Hansen, M. T., \& Nohria, N. (2004). How to build collaborative advantage. MIT Sloan Management Review, 46(1), 22.

Howells, J. (2000). The nature of innovation in services, report presented to the OECD 'Innovation and Productivity in Services Workshop", 31 October-3 November 2000. Sydney, Australia.

Huan, S. H., Sheoran, S. K., \& Wang, G. (2004). A review and analysis of supply chain operations reference (SCOR) model. Supply Chain Management: An International Journal.

Jothimani, D., \& Sarmah, S. (2014). Supply chain performance measurement for third party logistics. Benchmarking: An International Journal.

Kang, S., Moon, T., \& Moon, T. (2015). Impact of organizational competence on supply chain performance through supply chain collaboration. Indian Journal of Science and Technology, 8(12), 1-10.

Kim, C., Yang, K. H., \& Kim, J. (2008). A strategy for third-party logistics systems: A case analysis using the blue ocean strategy. Omega, 36(4), 522-534.

Klein-Schmeink, S., \& Peisl, T. (2013). Supply chain innovation and risk assessment (SCIRA) model Supply Chain Safety Management (pp. 309326): Springer.

Kwak, D.-W., Seo, Y.-J., \& Mason, R. (2018). Investigating the relationship between supply chain innovation, risk management capabilities and competitive advantage in global supply chains. International Journal of Operations \& Production Management.

Lee, S. M., Lee, D., \& Schniederjans, M. J. (2011). Supply chain innovation and organizational performance in the healthcare industry. International Journal of Operations \& Production Management.

Lin, Y., Wang, Y., \& Yu, C. (2010). Investigating the drivers of the innovation in channel integration and supply chain performance: A strategy orientated perspective. International Journal of production economics, 127(2), 320-332.

Mentzer, J. T., DeWitt, W., Keebler, J. S., Min, S., Nix, N. W., Smith, C. D., \& Zacharia, Z. G. (2001). Defining supply chain management. Journal of Business logistics, 22(2), 1-25.

Narayanan, S., Narasimhan, R., \& Schoenherr, T. (2015). Assessing the contingent effects of collaboration on agility performance in buyersupplier relationships. Journal of Operations Management, 33, 140-154.

Panayides, P. M., \& Lun, Y. V. (2009). The impact of trust on innovativeness and supply chain 
Jurnal Bisnis dan Manajemen, Volume 21, No. 2, September 2022, p. 100-113

performance. International Journal of production economics, 122(1), 35-46.

Ringle, C. M., Sarstedt, M., Mitchell, R., \& Gudergan, S. P. (2018). Partial least squares structural equation modeling in HRM research. The International Journal of Human Resource Management, 1-27.

Rutner, S. M., Gibson, B. J., \& Williams, S. R. (2003). The impacts of the integrated logistics systems on electronic commerce and enterprise resource planning systems. Transportation Research Part E: Logistics and Transportation Review, 39(2), 83-93.

Sen, T. K., \& Ghandforoush, P. (2011). Radical and incremental innovation preferences in information technology: an empirical study in an emerging economy. Journal of technology management \& innovation, 6(4), 33-44.

Simatupang, T. M., \& Sridharan, R. (2005). An integrative framework for supply chain collaboration. The International Journal of Logistics Management.

Soosay, C. A., Hyland, P. W., \& Ferrer, M. (2008). Supply chain collaboration: capabilities for continuous innovation. Supply Chain Management: An International Journal.

Stefansson, G. (2002). Business-to-business data sharing: A source for integration of supply chains. International Journal of production economics, 75(1-2), 135-146.

Swink, M. (2006). Building collaborative innovation capability. Research-technology management, 49(2), 37-47.

Tian, Y., Ellinger, A. E., \& Chen, H. (2010). Thirdparty logistics provider customer orientation and customer firm logistics improvement in China. International journal of physical distribution \& logistics management.

Tsanos, C. S., \& Zografos, K. G. (2016). The effects of behavioural supply chain relationship antecedents on integration and performance. Supply Chain Management: An International Journal.

Wu, L., Chuang, C.-H., \& Hsu, C.-H. (2014). Information sharing and collaborative behaviors in enabling supply chain performance: A social exchange perspective. International Journal of production economics, 148, 122-132.

Zaroni, CISCP., CFMP. (2017). Daya saing perusahaan penyedia jasa logistik Nasional. Artikel Supply Chain Indonesia. 